\title{
Catalysis of hydrazone and oxime peptide ligation by arginine
}

\author{
Nathalie Ollivier, ${ }^{\text {a }}$ Vangelis Agouridas,,${ }^{\mathrm{a}, \mathrm{b}}$ Benoît Snella, ${ }^{\mathrm{a}}$ Rémi Desmet, ${ }^{\mathrm{a}}$ Hervé Drobecq, ${ }^{\mathrm{a}}$ Jérôme \\ Vicogne, ${ }^{\mathrm{a}}$ Oleg Melnyk ${ }^{\mathrm{a}} *$ \\ ${ }^{a}$ Univ. Lille, CNRS, Inserm, CHU Lille, Institut Pasteur de Lille, U1019 - UMR 9017 - CIIL - Center for Infection and \\ Immunity of Lille, F-59000 Lille, France \\ ${ }^{\mathrm{b}}$ Centrale Lille, F-59000 Lille, France
}

\section{Supporting Information Placeholder}

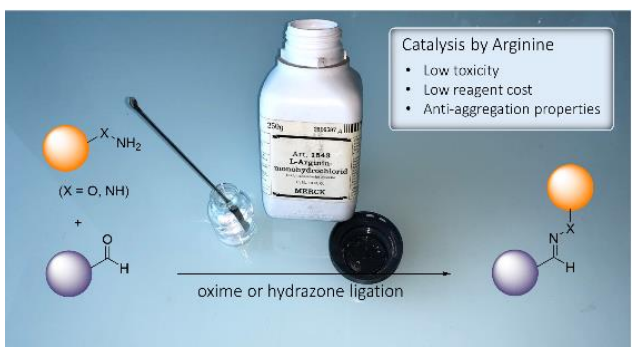

\begin{abstract}
Hydrazone and oxime peptide ligations are catalyzed by arginine. The catalysis is assisted intramolecularly by the side-chain guanidinium group. Hydrazone ligation in the presence of arginine proceeds efficiently in phosphate buffer at neutral $\mathrm{pH}$ but is particularly powerful in bicarbonate/ $\mathrm{CO}_{2}$ buffer. In addition to acting as a catalyst, arginine prevents the aggregation of proteins during ligation. With its dual properties as nucleophilic catalyst and protein aggregation inhibitor, arginine hydrochloride is a useful addition to the hydrazone/oxime ligation toolbox.
\end{abstract}

Imine-based reactions leading to the formation of hydrazones or oximes $(\mathrm{X}=\mathrm{N}$ or $\mathrm{O}$ respectively, Figure 1) are popular bioconjugation techniques recognized for their ease of

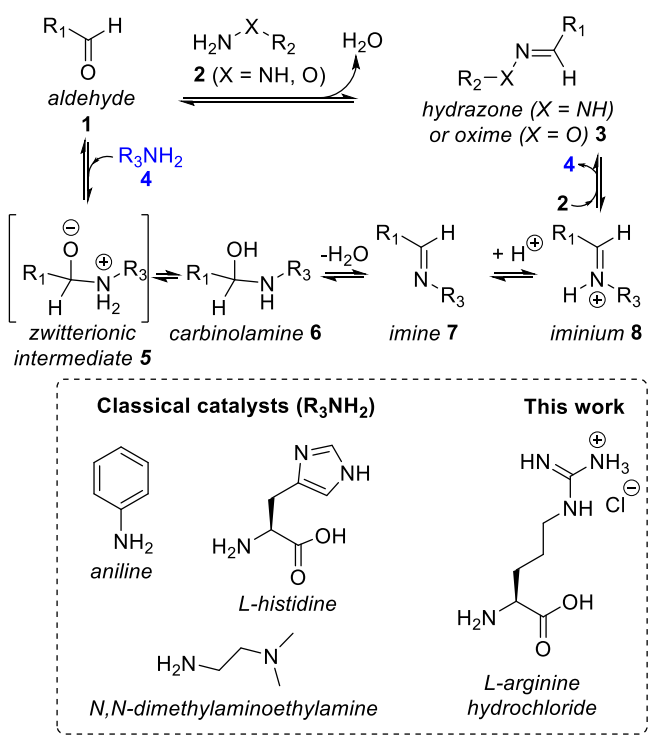

Figure 1. Principle of hydrazone or oxime ligations and of their nucleophilic catalysis by amine compounds. $R_{1}, R_{2}=$ Biomolecules, dyes, etc...

implementation, their high chemoselectivity in water and their compatibility with a wide range of substrates including polypeptides, nucleic acids and nanomaterials. ${ }^{1,2}$ Hydrazone and oxime formation show useful reaction rates at mildly acidic $\mathrm{pH}$ (4-5) but are very slow processes in water at neutral $\mathrm{pH}$, which is the preferred media for manipulating complex biomolecules such as proteins. As a consequence, many studies focused on accelerating these reactions by thermal activation, ${ }^{3}$ by freezing, ${ }^{4}$ by protein-protein complex formation, ${ }^{5}$ by addition of organic co-solvents ${ }^{3}$ or catalysts. ${ }^{1,6-9}$ Nucleophilic catalysis by amine compounds such as aniline ${ }^{6,8}$ (or derivatives thereof $^{10,11}$ ) or $N, N$-dimethylaminoethylamine ${ }^{7,12}$ has proven especially powerful in this regard (Figure 1).

In such a process, the amine catalyst 4 combines with the aldehyde $\mathbf{1}$ to produce imine $\mathbf{7}$, which undergoes a transimination with hydrazine or hydroxylamine derivative $\mathbf{2}$ through iminium species 8. The action of $N, N$ dimethylaminoethylamine involves an intramolecular acidcatalysis by the protonated $\mathrm{N}, \mathrm{N}$-dimethylamino group which considerably accelerates the formation of the imine product of type 7 by facilitating water elimination from carbinolamine $\mathbf{6}$ (Figure 1). ${ }^{7}$ In an analogous way, histidine has been shown to catalyze hydrazone or oxime bond formation, likely by favoring 
the dehydration of carbinolamine $\mathbf{6}$ through intramolecular acid catalysis by the imidazolium side chain group. ${ }^{12,13}$

Despite a great interest with regard to reagent cost, operational advantages, low toxicity and adherence to sustainable chemistry principles,${ }^{14}$ only a few works have examined the catalysis of hydrazone or oxime ligations by proteinogenic amino acids. Hereinafter, we report that the amino acid arginine catalyzes hydrazone or oxime bond formation in phosphate buffer at neutral $\mathrm{pH}$. Detailed kinetic studies suggest that the side-chain guanidinium group plays a crucial role in the catalysis mechanism. We also show that the rate of arginine-catalyzed hydrazone ligation is dramatically enhanced in bicarbonate/ $\mathrm{CO}_{2}$ buffer, a classical buffer used for cell culture.

The model hydrazone ligations used for investigating the catalytic properties of arginine, added in the reactions as arginine hydrochloride, and other additives are shown in Figure 2 . The hydrazide and $\alpha$-oxo aldehyde functionalities were chosen for being popular and easily installed on peptides or proteins through synthetic or semi-synthetic methods. ${ }^{15,16}$

In a first series of experiments, hydrazone ligation was performed with model peptides 8a and 9a in pH 7.0 sodium phosphate buffer at $25^{\circ} \mathrm{C}$ at $1 \mathrm{mM}$ peptide concentration and $50 \mathrm{mM}$ concentration for the additives. The progress of the reaction was monitored by measuring the absorbance of the hydrazone product $\mathbf{1 0 a}$ at $285 \mathrm{~nm}$. Kinetic data were fitted to extract the apparent second order rate constants. The reaction mixtures were also analyzed by LC-MS. Figure 3a shows that the catalytic potency of arginine hydrochloride is $\sim 3$ fold that of alanine. The relationship between arginine concentration and the rate of hydrazone formation is remarkably linear, with a break at $\sim 400 \mathrm{mM}$ (Figure $3 \mathrm{~b}$ ). At this catalyst concentration, hydrazone ligation is a fast process with a $\mathrm{k}_{\mathrm{app}}$ of $\sim 10 \mathrm{M}^{-1} \mathrm{~min}$ 1 . Arginine hydrochloride was found to catalyze ketoxime bond formation as well at $\mathrm{pH} 6.0$ or 7.0 (see Supplementary Information).
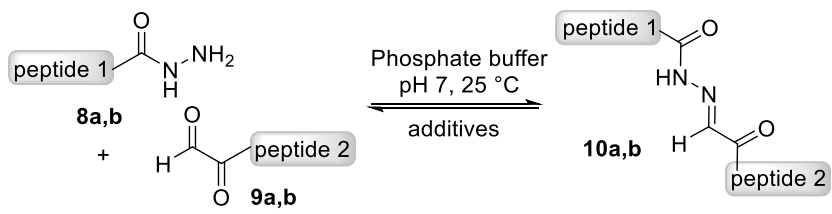

peptide 8a: Ac-ALKEPVHGVSGSA-CONHNH

peptide 8b: $\quad$ SUMO-1 (2-97)

SHLKSKKGQSTSRHKKLMFXTEGPDS-CONHNH

peptide 9a: CHOCO-ALKEPVHGV-NH $\mathrm{N}_{2}$

peptide 9b: CHOCO-GSGSGSGKPIPNP

LLGLDSTGSGSGS-NH

Figure 2. Model hydrazone ligations examined in this study.

The reaction between 8a and 9a was also catalyzed by histidine as reported for other types of aldehyde substrates. ${ }^{12,13}$ In this case however, the reaction yielded a significant amount of sideproduct in addition to the expected hydrazone. This sideproduct was identified as the $\alpha$-oxo aldehyde/histidine condensate, thereby discarding the use of histidine as a suitable catalyst for hydrazone ligation with $\alpha$-oxo aldehydes (see Supplementary Information). Note that the formation of cyclics adducts by reaction of histidine or histamine with aldehydes has been described by several groups. ${ }^{17-19}$ Therefore, arginine is the best proteinogenic amino acid described so far for catalyzing hydrazone formation with $\alpha$-oxo aldehydes.
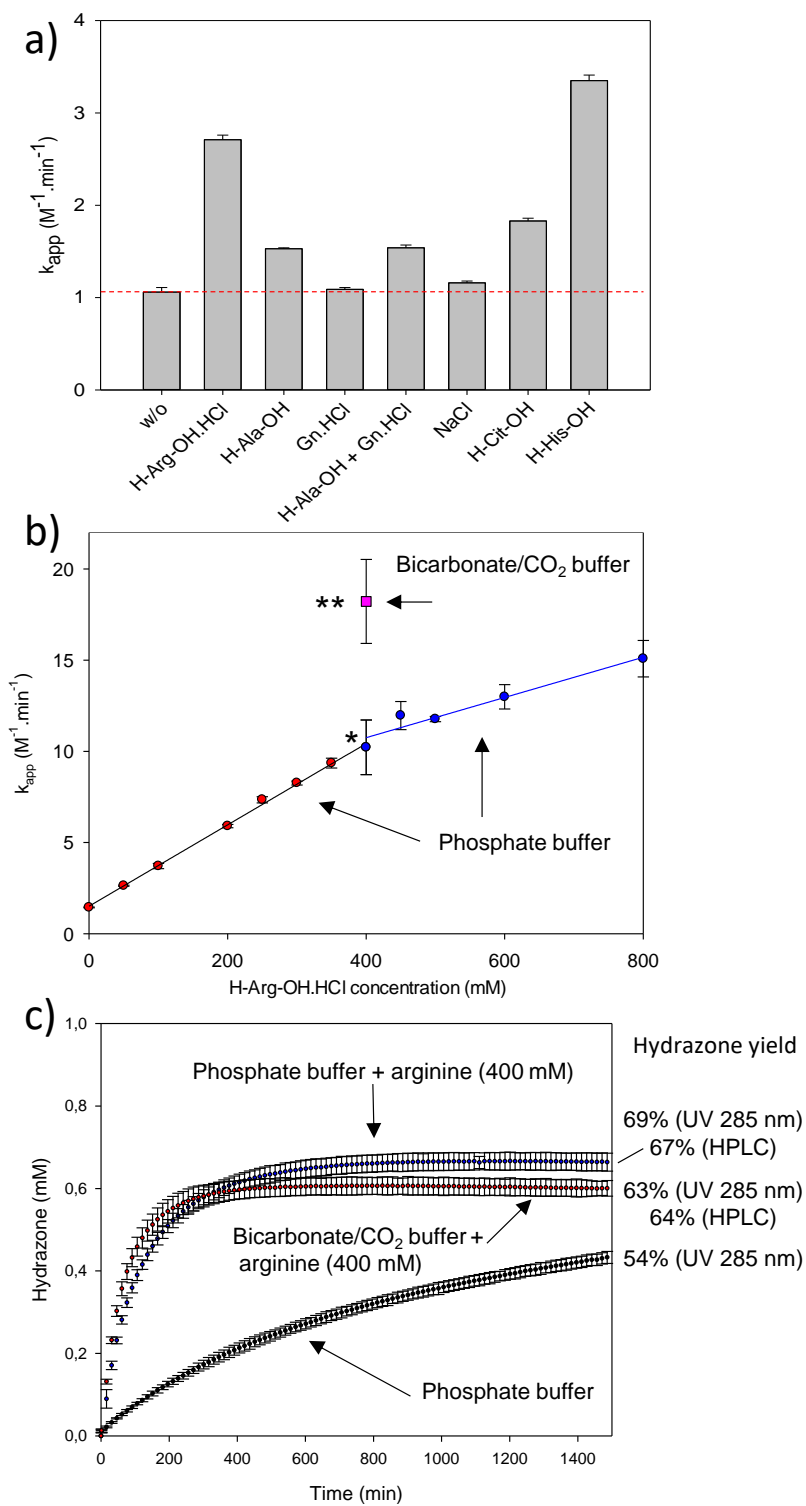

Figure 3. Apparent second order rate constant of hydrazone 10a formation in the presence of amino acid and/or salt additives. Sodium phosphate buffer $0.1 \mathrm{M}, \sim 1 \mathrm{mM}$ final concentration for each peptide, $\mathrm{pH} \sim 7,25^{\circ} \mathrm{C}$. The data correspond to the mean \pm standard error ( $95 \%$ confidence limit interval). a) The additive concentration was $50 \mathrm{mM}$. The reactions were performed in sextuplicate in one 96-well microtiter plate. The reaction with histidine is complicated by the formation of a covalent adduct between the CHOCO peptide and histidine catalyst in significant amounts (see Supplementary Information). b) Effect of H-Arg$\mathrm{OH} \cdot \mathrm{HCl}$ concentration on the apparent second order rate constant of hydrazone formation in $0.1 \mathrm{M}$ sodium phosphate (circles) or 40 $\mathrm{mM}$ bicarbonate/ $\mathrm{CO}_{2}$ buffer (square). * Mean of four independent experiments, each done in triplicate. ** Mean of five independent experiments, each done in triplicate. c) Time course of hydrazone 
10a formation from $8 \mathbf{a}(0.95 \mathrm{mM})$ and $9 \mathbf{a}(0.99 \mathrm{mM})$ at $25{ }^{\circ} \mathrm{C}$ in phosphate buffer $\mathrm{pH} 7.04$, phosphate buffer + arginine $(400 \mathrm{mM})$ $\mathrm{pH} 7.01$ or bicarbonate/ $\mathrm{CO}_{2}$ buffer + arginine $(400 \mathrm{mM}) \mathrm{pH} 7.07$.

At $50 \mathrm{mM}$ catalyst concentration, we found that $N, N$ dimethylaminoethylamine $\left(6.46 \pm 0.05 \mathrm{M}^{-1} \cdot \mathrm{min}^{-1}\right)$ or aniline $\left(6.8 \pm 0.23 \mathrm{M}^{-1} \cdot \mathrm{min}^{-1}\right)$ perform better than arginine $(2.71 \pm 0.05$ $\left.\mathrm{M}^{-1} \cdot \mathrm{min}^{-1}\right)$. However, raising arginine concentration to $200-250$ $\mathrm{mM}$ enables to achieve a $\mathrm{k}_{\text {app }}$ of $6-7 \mathrm{M}^{-1} \cdot \mathrm{min}^{-1}$ as well, with the advantage of using a catalyst of much lower toxicity. $\$$ Moreover, an interesting property of arginine hydrochloride is its well established capacity to inhibit protein aggregation. ${ }^{20} \mathrm{It}$ is a popular additive for protein refolding experiments and is frequently used at $\sim 0.5 \mathrm{M}$ concentration or higher for that purpose. Having a catalyst of hydrazone or oxime ligation that inhibits protein aggregation is a strong asset when it comes to work with complex protein targets (vide infra).

The data presented in Figure 3a show that sodium chloride, guanidine hydrochloride $(\mathrm{Gn} \cdot \mathrm{HCl})$, or alanine plus $\mathrm{Gn} \cdot \mathrm{HCl}$ were all far below the catalytic level of arginine hydrochloride. The same was observed for citrulline which has a neutral urea group in its side-chain in lieu of a guanidinium group as in arginine. These series of experiments suggest that the catalysis of the hydrazone ligation by arginine is based on an intramolecular catalytic participation of the side-chain guanidinium group. Contrary to tertiary ammonium of imidazolium cations, guanidinium cations are very weak acids including those found in arginine $\left(\mathrm{pK}_{\mathrm{a}}\right.$ 13.8). ${ }^{21}$ Logically, evidence for a role of arginine residue as an acid catalyst in enzymes are scarce. ${ }^{22,23}$ The occurrence of a general acidcatalysis of the carbinolamine dehydration step $(\mathbf{6} \rightarrow \mathbf{7}$ in Figure 1) by guanidinium cation, as observed for histidine or $N, N$ dimethylaminoethylamine, is therefore not obvious. Mechanisms other than general acid catalysis can impact imine formation. For example, some computational studies suggest that explicit water molecules can promote the dehydration of the carbinolamine $\mathbf{6}$ by facilitating an internal $\mathrm{N}-$ to-O proton shuffling mechanism. ${ }^{24}$ Interestingly, arginine is strongly suspected to act as a relay for proton transfers occurring in bacteriorhodopsin, ${ }^{25}$ pyridoxal 5'-phosphate synthase and other proteins. $^{26-28}$ The question whether the side-chain guanidinium cation of arginine promotes hydrazone formation by facilitating proton transfers, by acting as a general acid catalyst or by another mean will require more investigations.

At high arginine hydrochloride concentrations (e. g. $400 \mathrm{mM}$ ), a few percent of a byproduct corresponding to the conversion of the $\alpha$-oxo aldehyde moiety into a glycine residue was observed by LC-MS. We reasoned that the byproduct arose from a transamination of the $\alpha$-oxo aldehyde peptide by the excess of added arginine, a reaction that is known to be promoted by trace metals. In accord with this hypothesis, byproduct formation could be suppressed by adding disodium ethylenediaminetetraacetate (EDTA, $1 \mathrm{mM}$ ) to the ligation mixture (see Supplementary Information).

After having scrutinized the arginine-catalyzed hydrazone ligation using model peptides $\mathbf{8 a}$ and $\mathbf{9 a}$, we examined the reaction of protein hydrazide $8 \mathbf{b}(0.5 \mathrm{mM})$ with $\alpha$-oxo aldehyde peptide $9 \mathrm{~b}(2.5 \mathrm{mM})$ in the presence of arginine hydrochloride $(400 \mathrm{mM})$ in phosphate buffer $(\mathrm{pH} 7.0)$. Protein $\mathbf{8 b}$ is a fully synthetic $14 \mathrm{kDa}$ branched protein made of a SUMO-1 domain linked to a human p53 peptide. The sequence of peptide $\mathbf{9 b}$ corresponds to V5 peptidic tag. The ligation was monitored by SDS-PAGE followed by Western-blot analysis (Figure 4). The anti-SUMO-1 antibody was used to visualize protein hydrazide $\mathbf{8 b}$ and the hydrazone product $\mathbf{1 0 b}$, while anti-V5 antibody was used to reveal only the hydrazone product $\mathbf{1 0 b}$. These analyses show the successful formation of hydrazone product $\mathbf{1 0 b}$ whose identity was confirmed by LC-MS and proteomic analysis (see Supplementary Information). The equilibrium was reached in about $300 \mathrm{~min}$. The control experiment conducted in the absence of arginine catalyst failed to provide the expected protein hydrazone $\mathbf{1 0 b}$ due to protein precipitation (see Supplementary Information). This example is a nice illustration of the dual properties of arginine which acts as a catalyst of hydrazone bond formation and as an inhibitor of protein aggregation.

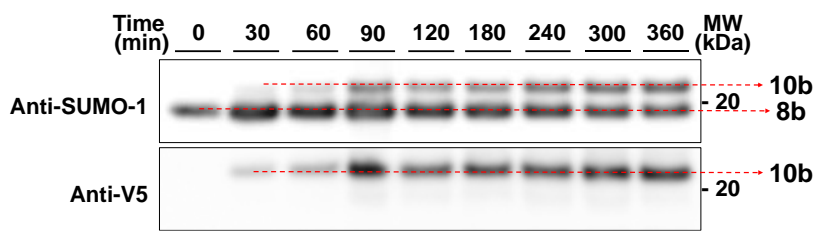

Figure 4. Western-blot analysis of hydrazone ligation between SUMO-1 p53 protein hydrazide $\mathbf{8 b}$ and $\alpha$-oxo aldehyde peptide $\mathbf{9 b}$. Synthesis of protein hydrazone $\mathbf{1 0 b}$. Conditions: $\mathbf{8 b} 0.5 \mathrm{mM}, \mathbf{9 b} 2.5$ $\mathrm{mM}$, arginine hydrochloride $400 \mathrm{mM}, 0.1 \mathrm{M}$ sodium phosphate buffer $\mathrm{pH} 7.0,25^{\circ} \mathrm{C}$.

After having validated the interest of arginine catalysis in phosphate buffer at the protein level, we were interested to know if catalysis proceeds also in bicarbonate/ $\mathrm{CO}_{2}$ buffer $(\mathrm{pH}$ 7.2-7.4), which is a classical buffering system used for cell culture media. Toward this end, an aqueous solution of sodium bicarbonate $(40 \mathrm{mM})$ was equilibrated for two days in a standard $\mathrm{CO}_{2}$ incubator for cell culture $\left(5 \% \mathrm{pCO}_{2}\right)$ and then used to dissolve arginine hydrochloride at $400 \mathrm{mM}$. With a resulting $\mathrm{pH}$ of $\sim 7.0$, the solution was used directly for performing the hydrazone ligation of peptides $\mathbf{8 a}$ and $9 \mathbf{a}$. We found that the rate constant for the arginine-catalyzed reaction in bicarbonate/ $\mathrm{CO}_{2}$ buffer $\left(18.2 \pm 2.3 \mathrm{M}^{-1} \cdot \mathrm{min}^{-1}\right)$ was almost twice that measured in phosphate buffer at the same $\mathrm{pH}$ (Figure $3 \mathrm{~b}$, pink square; Figure $3 \mathrm{c}$ ). Note that we verified that phosphate buffer concentration $(50-200 \mathrm{mM})$ had no effect on the rate of hydrazone formation whether arginine $(400 \mathrm{mM})$ is present or not (see Figure S 6). Thus, contrary to phosphate buffer, bicarbonate $/ \mathrm{CO}_{2}$ buffer plays a major role in the reaction and its combination with arginine enables to achieve rates as fast as $\sim 20 \mathrm{M}^{-1} \mathrm{~min}^{-1}$. It is tempting to suggest that bicarbonate ion might act through bifunctional acid-base catalysis and favor $\mathrm{N}$ to $\mathrm{O}$ proton transfers, as such mechanisms were observed for a few addition reactions occurring at carbonyls. ${ }^{29-31}$ However, the precise understanding of arginine hydrochloridebicarbonate/ $\mathrm{CO}_{2}$ system requires further investigations.

In conclusion, arginine hydrochloride catalyzes hydrazone and oxime bond formation in water at neutral $\mathrm{pH}$. The reaction can be performed in phosphate buffer but proceeds at a much faster rate in bicarbonate/ $\mathrm{CO}_{2}$ buffer. Arginine hydrochloride 
prevents the aggregation and precipitation of complex protein targets, is inexpensive, and shows low levels of toxicity. In that respect, arginine hydrochloride with its dual properties of nucleophilic catalyst and protein aggregation inhibitor is a useful addition to the hydrazone/oxime ligation toolbox.

\section{ASSOCIATED CONTENT}

\section{Supporting Information}

The Supporting Information is available free of charge on the ACS Publications website.

Experimental procedures, data fitting and characterization for all peptides (PDF file).

Data source file for kinetic studies (excel file)

\section{AUTHOR INFORMATION}

\section{Corresponding Author}

*oleg.melnyk@ibl.cnrs.fr.

\section{Author Contributions}

NO, VA and OM wrote the manuscript. / NO, BS and RD performed the experiments. VA performed the data fitting. JV and OM supervised the work. OM conceived the study. / All authors have given approval to the final version of the manuscript.

\section{Notes}

$\S \mathrm{N}, \mathrm{N}$-dimethylaminoethylamine is classified as a corrosive and toxic substance with an LD50 in rat $(1135 \mathrm{mg} / \mathrm{kg}) 10$ fold lower than those of arginine hydrochloride (12000 mg/kg, Source United States Environment Protection Agency). Aniline (LD50 in rat 780 $\mathrm{mg} / \mathrm{kg}$, European Chemical Agency) is suspected to be carcinogenic and mutagenic and is classified as class 3 toxic substance.

\section{ACKNOWLEDGMENT}

We thank CNRS, INSERM, Institut Pasteur de Lille and University of Lille for financial support.

\section{REFERENCES}

1. Kölmel, D. K.; Kool, E. T., Oximes and Hydrazones in Bioconjugation: Mechanism and Catalysis. Chem. Rev. 2017, 117, 10358-10376.

2. Algar, W. R.; Prasuhn, D. E.; Stewart, M. H.; Jennings, T. L.; Blanco-Canosa, J. B.; Dawson, P. E.; Medintz, I. L., The Controlled Display of Biomolecules on Nanoparticles: A Challenge Suited to Bioorthogonal Chemistry. Bioconjugate Chem. 2011, 22, 825-858.

3. Shao, J.; Tam, J. P., Unprotected Peptides as Building Blocks for the Synthesis of Peptide Dendrimers with Oxime, Hydrazone, and Thiazolidine Linkages. J. Am. Chem. Soc. 1995, 117, 3893-3899.

4. Agten, S. M.; Suylen, D. P. L.; Hackeng, T. M., Oxime Catalysis by Freezing. Bioconjugate Chem. 2016, 27, 42-46.

5. Agten, S. M.; Koenen, R. R.; Ippel, H.; Eckardt, V.; von Hundelshausen, P.; Mayo, K. H.; Weber, C.; Hackeng, T. M., Probing Functional Heteromeric Chemokine Protein-Protein Interactions through Conformation-Assisted Oxime Ligation. Angew. Chem. Int. Ed. 2016, 55, 14963-14966.

6. Cordes, E. H.; Jencks, W. P., Nucleophilic Catalysis of Semicarbazone Formation by Anilines. J. Am. Chem. Soc. 1962, 84 826-831.

7. Hine, J.; Cholod, M. S.; Chess, W. K., Kinetics of the Formation of Imines from Acetone and Primary Amines. Evidence for
Internal Acid-Catalyzed Dehydration of Certain Intermediate Carbinolamines. J. Am. Chem. Soc. 1973, 95, 4270-4276.

8. Dirksen, A.; Hackeng, T. M.; Dawson, P. E., Nucleophilic Catalysis of Oxime Ligation. Angew. Chem. Int. Ed. 2006, 45, 75817584.

9. Dirksen, A.; Dirksen, S.; Hackeng, T. M.; Dawson, P. E. Nucleophilic Catalysis of Hydrazone Formation and Transimination: Implications for Dynamic Covalent Chemistry. J. Am. Chem. Soc. 2006, 128, 15602-15603.

10. Wendeler, M.; Grinberg, L.; Wang, X.; Dawson, P. E.; Baca, M., Enhanced Catalysis of Oxime-Based Bioconjugations by Substituted Anilines. Bioconjugate Chem. 2014, 25, 93-101.

11. Zhou, Y.; Piergentili, I.; Hong, J.; van der Helm, M. P.; Macchione, M.; Li, Y.; Eelkema, R.; Luo, S., Indoline Catalyzed Acylhydrazone/Oxime Condensation under Neutral Aqueous Conditions. Org. Lett. 2020, 22, 6035-6040.

12. Larsen, D.; Kietrys, A. M.; Clark, S. A.; Park, H. S.; Ekebergh, A.; Kool, E. T., Exceptionally Rapid Oxime and Hydrazone Formation Promoted by Catalytic Amine Buffers with Low Toxicity. Chem. Sci. 2018, 9, 5252-5259.

13. Larsen, D.; Pittelkow, M.; Karmakar, S.; Kool, E. T., New Organocatalyst Scaffolds with High Activity in Promoting Hydrazone and Oxime Formation at Neutral pH. Org. Lett. 2015, 17, 274-277.

14. Collins, T., Toward Sustainable Chemistry. Science 2001, 291, 48-49.

15. El-Mahdi, O.; Melnyk, O., Alpha-Oxo Aldehyde or Glyoxylyl Group Chemistry in Peptide Bioconjugation. Bioconjugate Chem. 2013, 24, 735-765.

16. Zheng, J.-S.; Tang, S.; Qi, Y.-K.; Wang, Z.-P.; Liu, L., Chemical Synthesis of Proteins Using Peptide Hydrazides as Thioester Surrogates. Nat. Protocols 2013, 8, 2483-2495.

17. Rönnberg, A. L.; Hansson, C.; Drakenberg, T.; Håkanson, R., Reaction of Histamine with O-Phthalaldehyde: Isolation and Analysis of the Fluorophore. Anal. Biochem. 1984, 139, 329-337.

18. Kierska, D.; Sasiak, K.; Maśliński, C., Phosphopyridoxal Cyclic Compounds with Histamine and Histidine. 6: The Formation of Phosphopyridoxal Cyclic Compounds with Histamine and Histidine in the Presence of Biological Material. Agents and Actions 1978, 8, 470473.

19. Robert, L.; Penaranda, F. S., Studies on Aldehyde-Protein Interactions. I. Reaction of Amino Acids with Lower Aldehydes. J. Polym. Sci. 1954, 12, 337-350.

20. Lange, C.; Rudolph, R., Suppression of Protein Aggregation by L-Arginine. Curr. Pharm. Biotechnol. 2009, 10, 408-414.

21. Fitch, C. A.; Platzer, G.; Okon, M.; Garcia-Moreno, B. E.; McIntosh, L. P., Arginine: Its pKa Value Revisited. Protein Sci. 2015, 24, 752-61.

22. Keenholtz, R. A.; Mouw, K. W.; Boocock, M. R.; Li, N.-S.; Piccirilli, J. A.; Rice, P. A., Arginine as a General Acid Catalyst in Serine Recombinase-Mediated DNA Cleavage. J. Biol. Chem. 2013, 288, 29206-29214.

23. Silva, P. J.; Schulz, C.; Jahn, D.; Jahn, M.; Ramos, M. J., A Tale of Two Acids: When Arginine Is a More Appropriate Acid Than $\mathrm{H}_{3} \mathrm{O}^{+}$. J. Chem. Phys. B 2010, 114, 8994-9001.

24. Hall, N. E.; Smith, B. J., High-Level ab Initio Molecular Orbital Calculations of Imine Formation. J. Chem. Phys. A 1998, 102, 4930-4938.

25. Ge, X.; Gunner, M. R., Unraveling the Mechanism of Proton Translocation in the Extracellular Half-Channel of Bacteriorhodopsin Proteins: Structure, Function, and Bioinformatics 2016, 84, 639-654.

26. Moccand, C.; Kaufmann, M.; Fitzpatrick, T. B., It Takes Two to Tango: Defining an Essential Second Active Site in Pyridoxal 5'-Phosphate Synthase. PLOS ONE 2011, 6, e16042.

27. Chang, H.-C.; Kung, C. C. H.; Chang, T.-T.; Jao, S.-C.; Hsu, Y.-T.; Li, W.-S., Investigation of the Proton Relay System Operative in Human Cystosolic Aminopeptidase P. PLOS ONE 2018, 13 , e0190816.

28. Jao, S.-C.; Huang, L.-F.; Hwang, S.-M.; Li, W.-S., Tyrosine 387 and Arginine 404 Are Critical in the Hydrolytic Mechanism of Escherichia coli Aminopeptidase P. Biochemistry 2006, 45, 1547-1553. 
29. Barnett, R. E.; Jencks, W. P., Diffusion-Controlled Proton Transfer in Intramolecular Thiol Ester Aminolysis and Thiazoline Hydrolysis. J. Am. Chem. Soc. 1969, 91, 2358-2369.

30. Cunningham, B. A.; Schmir, G. L., Iminolactones. II. Catalytic Effects on the Nature of the Products of Hydrolysis. J. Am. Chem. Soc. 1966, 88, 551-558.
31. Eriksson, S. O., Hydrolysis of Anilides. IV. Hydroxylaminolysis, Hydrazinolysis, and General Acid-Catalysed Alkaline Hydrolysis of Trifluoroacetanilide. Acta Chem. Scand. 1968, 22, 892-906. 